V. Varavka, Master student

Institute of Postgraduate Education,

Taras Shevchenko National Univercity of Kyiv, Kyiv, Ukraine

\title{
SMART CONTRACT AS A FORM OF CIVIL CONTRACT
}

Development of information technologies, cryptocurrencies and technology of distributed networks has caused the appearance of smart contracts as new types of civil contract. They have been widely used in recent years in such areas as initial coins offering (ICO), financial sector, international trade and public services. At the same time the legal status and legal regulation of smart contracts are uncertain. These uncertainties cause many legal risks of smart-contracts utilization.

The purpose of this article is to find out the conception of smart contract as a form of civil contract, to research its legal status and legal regulation issues and to develop proposals for the improvement of legal regulation of smart contracts and cryptocurrencies in Ukraine. By its legal nature a smart contract is a digital form of a civil contract realized in programming code automatically executed in a distributed network. Like a civil contract, smart contract has such elements as parties, subject and essential terms of the contract. The legal force of a smart contract depends on whether it includes the fundamental features of a civil contact, such as evidence that parties have intention to create legal relations, understandability of contract conditions and possibility to perform the terms of the contract under duress. The main advantages of a smart contract are its ability to significantly accelerate and reduce costs of the transaction and guarantee the fulfillment of contract terms regardless of the contractual parties' and third parties' will. The main risks of a smart contract are uncertainty of legal status of a smart contract and cryptocurrencies as a means of payment, complexity of expressing the contact terms in a mathematical algorithm, risk of software bugs and hacking attack. To solve the problems of legal regulation of smart contracts in Ukraine it is necessary to change the legislation in order to settle the legal status of cryptocurrencies and recognize a smart contract as a form of a civil contract. It is necessary to identify parties of the smart contract, confirm their agreement on the terms of the smart contract by using digital electronic signature. A smart contract should be supplemented by text application containing the essential terms of the contract which will have legal force in trail. It is necessary to implement blockchain technology in the state registers and provide legal ability to make adjustments in the registers automatically for the performance of smart contracts.

Keywords: contract, smart contract, cryptocurrency, distributed network, enforceability of a smart contract, legal regulation.

Bulletin of Taras Shevchenko National University of Kyiv. Legal Studies, 2019; 4 (111): 20-24

УДК: $341.96: 347.627 .3$

DOI: https:doi.org/10.17721/1728-2195/2019/4.111-4
ISSN 1728-2195

(C) Taras Shevchenko National University of Kyiv, Publishing center "Kyiv University", 2019

О. Верба-Сидор, канд. юрид. наук, доц. ORCID ID: 0000-0001-9254-9575,

У. Воробель, канд. юрид. наук ORCID ID: 0000-0003-0480-5394

Львівський державний університет внутрішніх справ, Львів, Україна

\section{ФОРМАЛЬНА СЕПАРАЦІЯ ЯК УМОВА РОЗІРВАННЯ ШЛЮБУ У ЗАКОНОДАВСТВІ ДЕРЖАВ-УЧАСНИЦЬ ЄВРОПЕЙСЬКОГО СОЮЗУ (ДАНІЯ, ІРЛАНДІЯ ТА ІТАЛІЯ)}

Проаналізовано законодавчі положення інституту сепарації тих держав-учасниць ЄС, що обрали для себе модель правового регулювання сепарації, відповідно до якої визнається безпосередня залежність розірвання шлюбу від сепарації, тобто той із подружжя, хто бажає розірвати шлюб, повинен деякий час перебувати у стані сепарації, оформленої рішенням компетентного органу (формальної сепарації). Окреслену модель правового регулювання сепарації обрали для себе такі держави-учасниці ЄС, як Данія, Ірландія та Італія. Виокремлено характерні риси цієї моделі правового регулювання інституту сепарації, зокрема встановлено, що основною метою закріплення в законодавстві цих держав інституту сепарації є можливість надати подружжю час для визначення того майбутнього для їхнього шлюбу, яке вони бажають обрати: розлучення чи примирення; режим окремого проживання може бути встановлений за рішенням компетентного органу (суду, прокурора, державної адміністрації) за взаємною згодою чи на вимогу одного з подружжя попри заперечення іншого; наявність чіткого переліку підстав у законодавстві для встановлення сепарації за заявою одного з подружжя; існування тих чи інших наслідків режиму окремого проживання пов'язується із визначенням вини одного чи обох із подружжя у встановленні режиму окремого проживання на тій чи іншій підставі; установлення сепарації веде до припинення режиму спільності майна подружжя, набутого у шлюбі, припинення дії илюбного договору, крім положень щодо режиму окремого проживання та припинення дії презумпції батьківства.

Ключові слова: режим окремого проживання подружжя, розірвання шлюбу, правові наслідки, режим майна, шлюбний договір, презумпція батьківства.

ВСТУП. Сім'я як первинний та основний осередок суспільства перебуває під особливою охороною держави. Серед виявів такої охорони $є$ створення державою системи гарантій збереження цілісності сім'ї, зокрема шляхом правового регулювання тих інститутів, які спрямовані на сприяння подружжю у збереженні їхнього шлюбу. Серед них $€$ інститут окремого проживання подружжя, який у світовій практиці більше відомий як сепарація [1, с. 90-91]. Незважаючи на те, що становлення інституту окремого проживання подружжя (сепарації) у праві України мало довготривалу та непросту історію, практика застосування цього інституту свідчить про важливість та доцільність його запровадження. Успішним $€$ і досвід застосовування інституту сепарації у багатьох іноземних державах, зокрема учасницях Європейського Союзу (далі - ЄС).
У науковій літературі виокремлюють три моделі правового регулювання режиму окремого проживання подружжя у різних країнах:

1) модель, яка ґрунтується на самостійності інститутів сепарації та розірвання шлюбу;

2) модель, під час застосування якої не розрізняють підстав для сепарації та розірвання шлюбу - саме подружжя має зробити вибір щодо застосування того чи іншого інституту;

3) модель, відповідно до якої визнається безпосередня залежність розірвання шлюбу від сепарації, тобто той із подружжя, хто бажає розірвати шлюб, повинен деякий час перебувати у стані сепарації, оформленої рішенням компетентного органу (формальної, а не фактичної сепарації, за якої подружжя не проживає разом із власної волі та не звертається за 
оформленням такого стану до жодних уповноважених органів) [2, с. $41 ; 3$, с. $117-118 ; 4$, с. $128-129 ; 5$, с. 127 ; 6 , с. $165 ; 7$, с. $82-83 ; 8$, с. 22$]$

На нашу думку, доцільно виокремити і четверту модель правового регулювання інституту сепарації, а саме модель, за якої фактичне окреме проживання (фактична сепарація) $є$ однією із законодавчо передбачених підстав для розірвання шлюбу.

Особливості правового регулювання сепарації в іноземних державах, а саме у державах-учасницях $\epsilon C$, були об'єктом дослідження чималої кількості українських науковців. Значний внесок у висвітлення цього питання зроблено О. О. Білик у дисертаційному дослідженні, присвяченому саме інституту окремого проживання подружжя у сімейному праві [2]. Інститут сепарації у контексті порівняльно-правової характеристики досліджено також К. М. Глиняною, Т.М.Лежнєвою, $\begin{array}{lll}\text { Л. В. Липець, } & \text { В. М. Старчумко, } & \text { О. В. Старчук, }\end{array}$ С. В. Черноп'ятовим та ін. Однак більшість цих учених увагу зосереджували на дослідженні інституту сепарації окремих держав.

Метою нашої статті $€$ аналіз положень правового регулювання сепарації (окремого проживання подружжя) тих держав-учасниць ЄС, які належать до третьої, уже згаданої вище, моделі правового регулювання сепарації, відповідно до якої визнається безпосередня залежність розірвання шлюбу від формальної (юридичної) сепарації, тобто той із подружжя, хто бажає розірвати шлюб, повинен деякий час перебувати у стані сепарації, оформленої рішенням компетентного органу. Окреслену модель правового регулювання сепарації обрали для себе такі держави-учасниці ЄС, як Данія, Ірландія, Італія, Мальта та Литва.

ВИКЛАД ОСНОВНОГО МАТЕРІАЛУ. У Королівстві Данія питання, пов'язані з укладенням і розірванням шлюбу, а також визнанням його недійсним, регулюються однойменним законом - Законом "Про укладення та розірвання шлюбу" (AEgteskabsloven), а також прийнятими на його підставі підзаконними нормативноправовими актами [9, с. 22].

У 2013 році в Данії відбулася новелізація законодавчого регулювання шлюбно-сімейних відносин ${ }^{1}$, яка спростила процедуру розлучення подружжя у випадку згоди на розірвання шлюбу обох із подружжя шляхом відмови від необхідності попереднього періоду сепарації подружжя та вказівки на причини розлучення [11, c. 4]. Якщо при цьому між подружжям ще врегульовані аліментні зобов'язання, то рішення у такій справі приймається доволі швидко [9, с. 22].

У разі незгоди одного з подружжя на розірвання шлюбу призначається сепарація терміном на 6 місяців, після спливу якого у кожного з подружжя виникає право вимагати розлучення, незважаючи на відсутність згоди іншого з подружжя на розірвання шлюбу.

Законодавство Данії передбачає також право на розірвання шлюбу без згоди другого з подружжя і без установлення сепарації у таких випадках: 1) відсутність відносин між подружжям протягом останніх 2 років у зв'язку з їхньою несумісністю (§ 32 Закону "Про укла-

12.06.2013 року був прийнятий Закон № 647 "Про внесення змін до Закону "Про обласну державну адміністрацію", Закону "Про аліменти на дитину", Закону "Про шлюб та розірвання шлюбу" та до інших законів внаслідок зміни організації державних адміністрацій (Lov nr. 647 af 12.06.2013. Lov om ændring af lov om regional statsforvaltning, lov om børns forsørgelse, lov om ægteskabs indgåelse og opløsning og forskellige andre love som følge af ændret organisering af statsforvaltningerne [10]. дення та розірвання шлюбу"); 2) невірність. Проте заява про розірвання шлюбу з цієї підстави може бути подана особою або протягом шести місяців від дня, коли вона дізналася про здійснення іншим з подружжя перелюбу, або протягом двох років із дня вчинення такого діяння (§ 33 Закону "Про укладення та розірвання шлюбу"); 3) фрізичне або психічне насильство або вчинення насильства сексуального характеру щодо іншого з подружжя, близьких родичів або дітей, як спільних, так і інших. Для розірвання шлюбу з цієї підстави позовна заява має бути подана протягом одного року з моменту, коли про вчинення такого насильства дізнався інший із подружжя, або протягом трьох років 3 моменту його вчинення (§ 34 Закону "Про укладення та розірвання шлюбу"); 4) наявність іншого зареєстрованого шлюбу (§ 35 Закону "Про укладення та розірвання шлюбу"); 5) викрадення дитини (вивезення або утримання одним із подружжя дитини за межами держави). У цьому випадку позов про розірвання шлюбу може бути поданий, допоки дитина проживає за кордоном або не пізніше одного року після її повернення до країни (§ 36 Закону "Про укладення та розірвання шлюбу") [12].

Справа про сепарацію та/або розлучення подається до державної адміністрації (statsforvaltning). Statsforvaltning не може видати рішення про сепарацію чи розлучення, якщо сторони не врегулювали питання щодо аліментів на користь один одного. У разі, коли спір між подружжям не може бути вирішений у statsforvaltning, справа за заявою сторін передається до суду [9, с. 22].

Щодо правових наслідків встановлення сепарації, то вони такі ж, як і у розлучення шлюбу. Єдиним, що розмежовує ці два інститути, є те, що під час сепарації ніхто з подружжя не має права укладати нового шлюбу 3 іншою особою.

Сепарація припиняється з моменту відновлення подружніх відносин або продовження співжиття (§ 31 Закону "Про укладення та розірвання шлюбу") [12].

В Ірландії відповідно до ст. 5 (1) Акта сімейного права (розлучення) 1996 р. (Family Law (Divorce) Act, 1996 [13]) суд може ухвалити рішення про розірвання шлюбу, якщо буде доведено, що на момент подання відповідної заяви подружжя проживало окремо протягом щонайменше чотирьох із останніх п'яти років; нерозумно очікувати від них примирення; належні, на думку суду, положення прийняті чи будуть прийняті в умовах, що існують для подружжя і будь-кого зі залежних членів сім'ї [2, с. 222].

Закон про сепарацію та реформування сімейного права 1989 року (Judicial Separation and Family Law Reform Act, 1989) [14] у ст. 2 визначає такі підстави для встановлення сепарації: 1) якщо один із подружжя вчинив зраду; 2) якщо один із подружжя поводиться незрозуміло або жорстоко; 3) якщо один із подружжя покинув сім'ю на рік; 4) якщо подружжя не проживає разом більше одного року і обидва погоджуються на встановлення сепарації; 5) якщо подружжя не проживає спільно більше трьох років; 6) відбувся розрив шлюбних відносин настільки, що суд може зробити висновок, що нормальний шлюбний зв'язок не існує принаймні рік.

Сепарація може встановлюватися за вимогою одного із подружжя або за домовленістю сторін.

За законодавством Ірландії правові наслідки встановлення режиму окремого проживання подружжя полягають у тому, що суд під час ухвалення рішення про його встановлення звільняє подружжя від обов'язку 
спільно проживати, однак дружина все ще може носити прізвище чоловіка.

При прийнятті рішення про встановлення режиму окремого проживання суд має визначити того 3 подружжя, з ким проживатимуть діти, яким чином здійснюватиметься утримання дітей і участь того з батьків, хто проживає окремо, у вихованні дітей.

У разі смерті одного з подружжя, яке перебуває в режимі окремого проживання, той із подружжя, хто пережив іншого, зберігає усі законні права того з подружжя, якого пережив, окрім випадку, коли той із подружжя, що пережив, був визнаний судом винним у встановленні режиму окремого проживання.

На прохання одного з подружжя рішення суду про сепарацію може бути перетворено ірso iure на рішення про розірвання шлюбу за умови, що сепарація тривала три роки. У цьому випадку суддя ухвалює рішення про розірвання шлюбу та його наслідки. Якщо сепарація була встановлена за спільною заявою сторін, то вона трансформується у розірвання шлюбу лише у тому випадку, якщо сторони спільно подають заяву про розірвання шлюбу.

Режим окремого проживання припиняється, коли подружжям відновлено спільне проживання і це спільне життя підтверджує наміри до постійного спільного проживання надалі. Режим окремого проживання припиняється, коли за спільною заявою подружжя суд ухвалює рішення про його припинення, чим скасовує своє попереднє рішення про встановлення такого режиму [15].

Однак слід зазначити, що 24 травня 2019 року в Ірландії відбувся референдум щодо лібералізації процедури розлучення, на якому було прийнято рішення виключити з конституції країни вимогу щодо чотирирічного терміну перебування у сепарації, що дозволить ірландському парламенту (Oireachtas) прийняти закон про розірвання шлюбу із коротшим терміном перебування подружжя в режимі окремого проживання.

Законодавство Республіки Італія приділяє велику увагу режиму окремого проживання подружжя. Сепарація в італійському праві походить від конструкції, запровадженої канонічним правом, "відлучення від стола і ложа". Протягом тривалого часу режим окремого проживання символізував "розлучення католиків" і був єдиним юридичним рішенням, яке дозволяло чоловіку і дружині припинити спільне проживання, не конфліктуючи з принципом нерозривності шлюбу.

Iз запровадженням розлучення в італійське право законом від 1970 р. призначення режиму окремого проживання подружжя кардинально змінилося: проживання у режимі сепарації за рішенням суду безперервно протягом щонайменше останніх трьох років стало першим етапом розлучення [2, с. 86].

Важливі зміни відбулися у сімейному праві Італії відповідно до Закону № 55 від 06 травня 2015 року "Положення, що стосуються розірвання або припинення цивільних наслідків шлюбу, а також спільного проживання подружжя" (Disposizioni in materia di scioglimento o di cessazione degli effetti civili del matrimonio nonche di comunione tra i coniugi) [16]. Цим законодавчим актом термін окремого проживання як підстава для розлучення був зменшений із трьох років до одного року і шести місяців у випадку наявності згоди між подружжям на припинення шлюбу, навіть якщо ця згода виникла в процесі розгляду справи (наприклад, коли подружжя початково звернулося до суду з приводу встановлення судової сепарації, а згодом вона була змінена на сепарацію за домовленістю). Цей термін починає спливати 3 моменту появи подружжя перед головуючим суддею, тобто подання заяви про встановлення режиму окремого проживання [2, с. 87]. Для встановлення сепарації не має значення, чи у подружжя є діти [17].

Інститут сепарації урегульований у п'ятій главі "Про розірвання шлюбу та сепарацію подружжя" (Capo V Dello scioglimento del matrimonio e della separazione dei coniugi) шостого розділу "Про шлюб" (Titolo VI Del matrimonio) книги першої "Про осіб та сім'ю" (Libro Primo Delle persone e della famiglia) Цивільного кодексу Італії [18] (далі - ЦК Італії). Кодекс передбачає дві форми сепарації: судова (separazione giudiziale) і за домовленістю сторін (separazione consensuale) (ст. 150 ЦК Італії). Паралельно з ними існує ще третя форма, яка не знайшла комплексного регулювання, однак окреслена наукою права як "тимчасова сепарація" [19, с. 233]. Вона може настати в ході провадження про визнання шлюбу недійсним, сепарацію або про розірвання шлюбу. Ці три іпостасі сепарації іменуються юридичною (формальною) сепарацію, на відміну від фактичної сепарації, яка настає унаслідок рішення самих сторін без жодного втручання зі сторони суду [20, с. 18].

Отже, режим окремого проживання відповідно до італійського законодавства може бути встановлений рішенням суду за взаємною згодою чи на вимогу одного з подружжя, незважаючи на заперечення іншого [2, с. 87].

Згідно зі ст. 151 ЦК Італії можливість подання заяви про встановлення режиму окремого проживання існує, коли продовження спільного проживання $€$ неприйнятним чи може завдати серйозної шкоди вихованню дітей [2, с. 67]. У разі, коли неприйнятність спільного проживання виникає через винну поведінку одного з подружжя, яка породжує невиконання подружніх обов'язків, інший з подружжя може вимагати визнання вини першого при встановленні режиму окремого проживання судом. Визнання одного з подружжя винним має для нього/неї негативні майнові наслідки щодо утримання і спадкування (ч. 2 ст. 151 ЦК Італії) [2, с. 89].

Сепарація може бути встановлена й у випадку засудження одного із подружжя до довічного позбавлення волі, позбавлення волі на термін більше п'яти років або у випадку довічної втрати права на державну службу (ст. 152 ЦК Італії) [18].

У разі наявності бажання обох із подружжя на встановлення режиму окремого провадження необхідне лише звернення до суду для підтвердження факту сепарації (ст. 150 ЦК Італії) [21, с. 300]. У цьому разі суд має повноваження дослідити й оцінити домовленості, яких досягло подружжя щодо дітей, може вказати на необхідні зміни в інтересах дітей і відмовитися підтвердити сепарацію, якщо її наслідки будуть негативними [2, с. 88].

Як уже зазначалося, Закон № 55 від 06 травня 2015 року "Положення, що стосуються розірвання або припинення цивільних наслідків шлюбу, а також спільного проживання подружжя", який набрав чинності 26 травня 2015 року, а також декрет із силою закону від 12 вересня 2014 року № 132 внесли істотні зміни у правове регулювання сепарації, розлучення, а також припинення спільної власності подружжя [17].

Згідно з новим італійським законом для встановлення сепарації або розірвання шлюбу у разі спільної згоди подружжя вже не є обов'язковим їхнє звернення до суду. Подружжя може скористатися позасудовою процедурою - звернутися до адвоката або скористатися спрощеною процедурою у відповідній установі.

У першому випадку для встановлення сепарації подружжю достатньо звернутися до одного (спільного) 
або двох різних адвокатів (кожний із подружжя до свого), які уповноважені редагувати договір сторін, який і буде переданий до прокуратури (Procura della Repubblica) для підтвердження відсутності перешкод (у випадку відсутності малолітніх дітей) або його затвердження (у випадку наявності малолітніх дітей). В особливих випадках прокуратура може передати договір для аналізу голові суду з метою його верифрікації (коли подружжя має малолітніх дітей або договір передбачає нерівні умови щодо одного з подружжя, наприклад, коли йдеться про час спілкування дитини з одним із батьків). Адвокат передає засвідчений ним договір до відповідної установи реєстрації актів цивільного стану. Цей договір є повноцінним виконавчим документом [22].

Відповідно до останніх змін ст. 191 ЦК Італії у випадку встановлення режиму окремого проживання режим спільності майна подружжя, набутого у шлюбі, юридично припиняється у момент, коли головуючий у справі суддя дозволяє подружжю проживати окремо, чи з моменту, коли подружжя підписує протокол щодо встановлення режиму окремого проживання за взаємною згодою. Таке підписання має відбутися у присутності судді, і суддя затверджує протокол. Рішення суду, яким установлюється режим окремого проживання чи погоджується договір сторін щодо встановлення такого режиму, передається органам реєстрації актів цивільного стану для реєстрації з метою фріксування факту окремого проживання подружжя у свідоцтві про шлюб [2, с. 183; 17].

Згідно із ст. 548 ЦК Італії, той з подружжя, хто пережив, зберігає право спадкування, якщо його/ї̈ не було визнано винним у сепарації [2, с. 195; 23, с. 144].

ВИСноВКИ. Аналіз законодавчих положень тих держав-учасниць ЄС, у яких розірвання шлюбу безпосередньо залежить від формальної (юридичної) сепарації, дозволяє виокремити такі риси, притаманні цій моделі правового регулювання сепарації:

1) основною метою закріплення у законодавстві цих держав інституту сепарації $є$ можливість надати подружжю час для визначення того майбутнього для їхнього шлюбу, яке вони бажають обрати: розлучення чи примирення;

2) режим окремого проживання може бути встановлений за рішенням компетентного органу (суду, прокурора, державної адміністрації) за взаємною згодою чи на вимогу одного з подружжя попри заперечення іншого;

3) наявність чіткого переліку підстав у законодавстві для установлення сепарації за заявою одного 3 подружжя;

4) існування тих чи інших наслідків режиму окремого проживання пов'язується із визначенням вини одного чи обох із подружжя у встановленні режиму окремого проживання на тій чи іншій підставі;

5) встановлення сепарації веде до припинення режиму спільності майна подружжя, набутого у шлюбі, припинення дії шлюбного договору, крім положень щодо режиму окремого проживання та припинення дії презумпції батьківства.

I хоча ця модель правового регулювання сепарації нині ще залишається актуальною, однак тенденція до спрощення законодавчого регулювання процедури розірвання шлюбу, зокрема і в цих державах, зумовлює або цілковиту відмову від інституту сепарації як однієї з передумов розірвання шлюбу (у випадку взаємної згоди подружжя на припинення шлюбу), або ж зменшення терміну перебування подружжя у ній. Наприклад, Данія у 2013 році спростила процедуру розлучення подружжя у випадку згоди на розірвання шлюбу обох із подружжя шляхом відмови від необхідності попереднього періоду сепарації та вказівки на причини самого розлучення, а у випадку незгоди одного з подружжя на розірвання шлюбу термін сепарації зменшився до 6 місяців. В Італії у 2015 році термін окремого проживання як підстава для розірвання шлюбу був зменшений із трьох років до одного року і шести місяців у випадку наявності згоди між подружжям на припинення шлюбу. В Ірландії у 2019 році внаслідок референдуму була виключена із конституції держави вимога щодо чотирирічного терміну перебування подружжя у сепарації до звернення до суду із вимогою про розірвання шлюбу.

\section{Список використаних джерел:}

1. Воробель У. Б. Інститут окремого проживання подружжя (сепарація): історико-правові аспекти. Науковий вісник Львівського державного університету внутрішніх справ. Серія юридична. 2017. Вип. 2. C. $90-103$.

2. Білик О. О. Інститут окремого проживання подружжя в сімейному праві: порівняльно-правовий аспект : дис. ... канд. юрид. наук : 12.00.03. Київ, 2017. 258 с.

3. Лежнєва Т. М., Черноп'ятов С. В. Поняття та зміст режиму окремого проживання подружжя. Право і суспільство. 2010. № 6. С. 117-121.

4. Лепех С. Інститут сепарації: проблеми застосування. Право України. 2003. № 3. С. 128-130.

5. Старчук О. В. Розірвання шлюбу і режим окремого проживання подружжя: визначення змісту та співвідношення понять. Науковий вісник Ужгородського національного університету. Серія: Право. 2012. Випуск 20. Частина 1. Том 2. С. 126-128.

6. Цимбалюк В. І. Актуальні питання правового регулювання режиму окремого проживання подружжя в сімейному законодавстві України. Науковий вісник Міжнародного гуманітарного університету. Серія "Юриспруденція". 2014. Випуск 10-2. Том 1. С. 164-166.

7. Gręźlikowski Ja. Instytucja separacji w prawie europejskim. Studia Włocławskie. 2011. T. 13. S. 81-95.

8. Kaspryk P. Instytucja separacji małżeńskiej w świetle ustawy z dnia 21 maja 1999 roku. Lublin, Sandomierz, 1999. $141 \mathrm{~s}$

9. Хипели (Орийчук) Л. В. Формы семейных отношений и их отражение в законе в Дании. Права соотечественников Северной Европы. 2014. №. 2. С. 19-28.

10. Lov om ændring af lov om regional statsforvaltning, lov om børns forsørgelse, lov om ægteskabs indgåelse og opløsning og forskellige andre love som følge af ændret organisering af statsforvaltningerne. Lov nr. 647 af 12.06.2013. URL: https://www.retsinformation.dk/forms/r0710.aspx?id=151846 (дата звернення: 01.12.2019).

11. Petelczyc J., Skóra M. Zobowiązania alimentacyjne wobec dzieci w Danii i Wielkiej Brytanii. Warszawa: Kancelaria Senatu, 2017. 24 s.

12. Bekendtgørelse af lov om ægteskabs indgåelse og opløsning nr. 54 af 23. januar 2018, med de ændringer, der følger af $\S 1$ i lov nr. 1321 af 27. november 2018. URL: https://www.retsinformation.dk/Forms/ R0710.aspx?id=206338\#idce842498-75bf-4ef5-963b-273318857cb4 (дата звернення: 01.12.2019)

13. Family Law (Divorce) Act, 1996. Number 33 of 1996. URL: http://www.irishstatutebook.ie/eli/1996/act/33/enacted/en/html?q=Divorce (дата звернення: 01.12.2019).

14. Judicial Separation and Family Law Reform Act, 1989. Number 6 of 1989. URL: http://www.irishstatutebook.ie/eli/1989/act/6/enacted/en/html (дата звернення: 01.12.2019).

15. Europejska Sieć Sądownicza. Rozwód. Irlandia. URL: https://e-justice.europa.eu/content_divorce-45-ie-pl.do?member=1\#toc_1 (дата звернення: 01.12.2019).

16. Disposizioni in materia di scioglimento o di cessazione degli effetti civili del matrimonio nonche di comunione tra i coniugi. Legge 6 maggio 2015, № 55. Gazzetta Ufficiale della Repubblica Italiana. Roma, Lunedi, 11 maggio 2015. URL: http://www.gazzettaufficiale.it/eli/id/2015/05/11/ 15G00073/sg (дата звернення: 01.12.2019).

17. Separacja i rozwód we Włoszech. URL: https://naszswiat.it/ osiedlenie-sie/separacja-rozwod-we-wloszech/ (дата звернення: 01.12.2019).

18. Codice civile approvato con Regio Decreto del 16 marzo 1942, n. 262. Gazzetta Ufficiale, n. 79 del 4 aprile 1942. URL: http: https://www.altalex.com/documents/news/2014/11/10/dello-scioglimento-delmatrimonio-e-della-separazione-dei-coniugi (дата звернення: 01.12.2019).

19. Auletta T. II di famiglia. Torino : Giappichelli, 2000. 365 p.

20. Sylwestrzak A. Skutki prawne separacji małżonków: monografia. Warszawa: Wolters Kluwer Polska, 2017. $334 \mathrm{~s}$.

21. Білик О.О. Встановлення і припинення режиму окремого проживання подружжя: шляхи вдосконалення правового регулювання. Держава і право. Юридичні і політичні науки. 2013. Випуск 60. С. 298-305.

22. Kruk E., Kwapiński M. Separacja i rozwód w prawie włoskim. URL: https://www.polacywewloszech.com/2017/04/06/separacja-i-rozwod-wprawie-wloskim/ (дата звернення: 01.12.2019).

23. Білик О.О. Правові наслідки встановлення режиму окремого проживання подружжя. Держава і право. Юридичні і політичні науки. 2014. Випуск 65. С. 139-146. 
References:

1. Vorobel, U. B. (2017). Instytut okremoho prozhyvannia podruzhzhia (separatsiia): istoryko-pravovi aspekty [Institute of martial separation: historical and legal aspects]. Naukovyi visnyk Lvivskoho derzhavnoho universytetu vnutrishnikh sprav. Seriia yurydychna (The Scientific Bulletin of Lviv State University of Internal Affairs. Legal series), issues 2, 90-103 [in Ukrainian].

2. Bilyk, O. O. (2017). Instytut okremoho prozhyvannia podruzhzhia v simeinomu pravi: porivnialno-pravovyi aspekt [Institute of separate living of spouses in the family law: comparative legal aspect]: Doctor's thesis. Kyiv [in Ukrainian].

3. Lezhnieva, T. M., Chernop'iatov, S. V. (2010). Poniattia ta zmist rezhymu okremoho prozhyvannia podruzhzhia [The concept and content of judicial separation]. Pravo i suspilstvo (Law and Society), 6, 117-121 [in Ukrainian].

4. Lepekh, S. (2003). Instytut separatsii: problemy zastosuvannia [Separation Institute: problems of application]. Pravo Ukrainy (Law of Ukraine), 3, 128-130 [in Ukrainian]

5. Starchuk, O. V. (2012). Rozirvannia shliubu i rezhym okremoho prozhyvannia podruzhzhia: vyznachennia zmistu ta spivvidnoshennia poniat [Divorce and regime of spouse separation: determination of the content and correlation of the notions]. Naukovyi visnyk Uzhhorodskoho natsionalnoho universytetu. Seriia: Pravo (Uzhhorod National University Herald. Series: Law), issue 20, part 1, volume 2, 126-128 [in Ukrainian]

6. Tsymbaliuk, V. I. (2014). Aktualni pytannia pravovoho rehuliuvannia rezhymu okremoho prozhyvannia podruzhzhia $v$ simeinomu zakonodavstvi Ukrainy [Current issues of legal regulation for separation of spouses in family law of Ukraine]. Naukovyi visnyk Mizhnarodnoho humanitarnoho universytetu. Seriia lurysprudentsiia (Scientific herald of International Humanitarian University. Series: Jurisprudence), edition 10-2, volume 1, 164-166 [in Ukrainian].

7. Gręźlikowski, Ja. (2011). Instytucja separacji w prawie europejskim [Institution of separation in European law]. Studia Włocławskie (Włocławek Studies). Volume 13, 81-95 [in Polish]

8. Kaspryk, P. (1999). Instytucja separacji małżeńskiej w świetle ustawy z dnia 21 maja 1999 roku [The institution of marital separation in the light of the Act of May 21, 1999]. Lublin, Sandomierz [in Polish].

9. Hipeli (Orijchuk), L. V. (2014). Formy semejnyh otnoshenij i ih otrazhenie $v$ zakone $v$ Danii [Forms of family relations and their reflection in law in Denmark]. Prava sootechestvennikov Severnoj Evropy (Rights of compatriots of Northern Europe), 2, 19-28 [in Russian].

10. Lov om ændring af lov om regional statsforvaltning, lov om børns forsørgelse, lov om ægteskabs indgåelse og opløsning og forskellige andre love som følge af ændret organisering af statsforvaltningerne [Law on amending the law on regional state administration, the law on child support, the law on marriage and dissolution and various other laws as a result of changed organization of state administrations]. Lov nr. 647 af 12.06.2013. URL: https://www.retsinformation.dk/forms/r0710.aspx?id=151846 [in Danish]

11. Petelczyc, J., Skóra, M. (2017). Zobowiązania alimentacyjne wobec dzieci w Danii i Wielkiej Brytanii [Maintenance obligations for children in Denmark and the United Kingdom]. Warszawa: Kancelaria Senatu [in Polish].

12. Bekendtgørelse af lov om ægteskabs indgåelse og opløsning [Order of marriage and dissolution law] nr. 54 af 23. januar 2018, med de ændringer, der følger af $\S 1 \mathrm{i}$ lov nr. 1321 af 27 . november 2018. URL: https://www.retsinformation.dk/Forms/R0710.aspx?id=206338\#idce84249875bf-4ef5-963b-273318857cb4 [in Danish].

13. Family Law (Divorce) Act, 1996. Number 33 of 1996. URL: http://www.irishstatutebook.ie/eli/1996/act/33/enacted/en/html?q=Divorce [in English].

14. Judicial Separation and Family Law Reform Act, 1989. Number 6 of 1989. URL: http://www.irishstatutebook.ie/eli/1989/act/6/enacted/en/html [in English]

15. Europejska Sieć Sądownicza. Rozwód. Irlandia [European Judicial Network. Divorce. Ireland]. URL: https://e-justice.europa.eu/content_divorce45-ie-pl.do?member=1\#toc 1 [in Polish]

16. Disposizioni in materia di scioglimento o di cessazione degli effetti civili del matrimonio nonche di comunione tra i coniugi [Provisions regarding the dissolution or termination of the civil effects of marriage and of communion between spouses]. Legge 6 maggio 2015, № 55. Gazzetta Ufficiale della Repubblica Italiana (Official Journal of the Italian Republic). Roma, Lunedi, 11 maggio 2015. URL: http://www.gazzettaufficiale.it/ eli/id/2015/05/11/15G00073/sg [in Italian].

17. Separacja i rozwód we Włoszech [Separation and divorce in Italy]. URL: https://naszswiat.it/osiedlenie-sie/separacja-rozwod-wewloszech/ [in Polish]

18. Codice civile [Civil Code] approvato con Regio Decreto del 16 marzo 1942, n. 262. Gazzetta Ufficiale (Official Journal), n. 79 de 4 aprile 1942. URL: http: https://www altalex.com/documents/news/ 2014/11/10/dello-scioglimento-del-matrimonio-e-della-separazione-dei-coniugi [in Italian].

19. Auletta, T. (2000). II di famiglia [The family]. Torino: Giappichelli. [in Italian].

20. Sylwestrzak, A. (2017). Skutki prawne separacji małżonków [Legal effects of spouses separation]. Warszawa: Wolters Kluwer Polska [in Polish].

21. Bilyk, O. O. (2013). Vstanovlennia i prypynennia rezhymu okremoho prozhyvannia podruzhzhia: shliakhy vdoskonalennia pravovoho rehuliuvannia [Establishment and termination of regime of separate living of spouses: ways of improvement of legal regulation]. Derzhava $i$ pravo. Yurydychni i politychni nauky (State and law. Law and Political Science), issues 60, 298-305. [in Ukrainian]

22. Kruk E., Kwapiński, M. Separacja i rozwód w prawie włoskim [Separation and divorce in Italian law]. URL: https://www.polacywewloszech.com/2017/04/06/separacja-i-rozwod-w-prawiewloskim/ [in Polish].

23. Bilyk, O. O (2014) Pravovi naslidky vstanovlennia rezhymu okremoho prozhyvannia podruzhzhia [Legal consequences of spousal separate living regime establishment]. Derzhava i pravo. Yurydychni i politychni nauky (State and law. Law and Political Science), issues 65, 139-146. [in Ukrainian].

Received: $02 / 12 / 2019$ Accepted: $05 / 01 / 2020$

O. Verba-Sydor, Associate prof. (Civil Law), Disciplines Department U. Vorobel, Lecturer (Civil Law), Disciplines Department Lviv State University of Internal Affairs, Lviv, Ukraine

\section{FORMAL SEPARATION AS A CONDITION FOR THE DISSOLUTION OF MARRIAGE IN THE LEGISLATION OF EUROPEAN UNION MEMBER STATES (DENMARK, IRELAND AND ITALY)}

The institution of separation legislative provisions of those EU member states that have chosen a separation legal regulation model, according to which the direct dependence of divorce on separation is recognized. It means that the spouse who wishes to dissolve the marriage must be in a state of separation issued by competent authority decision for some time (formal separation).

Such EU member states as Denmark, Ireland, Italy have chosen the defined model for legal regulation of separation.

Based on this study, the characteristic features of this model for legal regulation of separation are highlighted, namely:

the main purpose of the separation institute in the legislation of these states is to provide spouses with time to decide on the future for their marriage: either divorce or reconciliation;

a separate residence regime may be established by a decision of the competent authority (court, prosecutor, public administration) by mutual agreement or at the request of one of the spouses, despite the objections of the other;

the existence of a clear list of grounds in the legislation to establish separation on the application of one of the spouses;

the existence of any consequences of the individual residence regime is linked to the determination of the fault of one or both spouses in the establishment of a separate residence regime on one or another basis;

separation would result in the termination of the marital property regime, the termination of the marriage contract, except for the provisions relating to the separate residence regime, and the termination of the paternity presumption.

Although this model for legal regulation of separation is still relevant, the trend toward the simplification of legal regulation of divorce proceedings, has led to the complete rejection of separation as one of the prerequisites for divorce (in the event of mutual consent of the spouses to the termination of marriage) or reduction of spouse's stay in separation.

Keywords: separate residence regime / separation regime, divorce, legal effect, property regime, marriage contract, presumption of paternity. 